\title{
Factors Affecting Millenials’ Acceptance of E-Money Application in Jakarta
}

\author{
Muhammad Reiza Indrawan $^{\mathrm{a} *}$; Daniel Livingstone ${ }^{\mathrm{b}}$; Rano Kartono ${ }^{\mathrm{c}}$; Arta Moro Sundjaja ${ }^{\mathrm{d}}$ \\ a,b,c,d Business Management, Binus Business School Master Program, Bina Nusantara University, Jl. Hang Lekir 1 No 6, \\ Senayan, Jakarta, 10270, Indonesia \\ a muhammad.indrawan001@ binus.ac.id; daniel.livingstone@binus.ac.id; ${ }^{c}$ rano.kartono@ binus.ac.id; ${ }^{\text {a } a s u n d j a j a @ b i n u s . e d u ~}$
}

Article History: Received: 10 November 2020; Revised 12 January 2021 Accepted: 27 January 2021; Published online: 5 April 2021

\begin{abstract}
The use of e-money applications such as OVO, Gopay, Dana, LinkAja and other e-money applications have significantly increased the volume of non-cash transactions in Indonesia, but, Indonesia's non-cash transaction is still below its region's countries. On the other hand, Millennial generations (Millenials) is reported as the largest users of e-money applications as well as the largest potential market in Indonesia, however, limited researches have been conducted to study the acceptance of e-money applications by Millennials. This research is intended to determine factors that have significantly influenced Millenial's acceptance of e-money applications based on the theory of Technology Acceptance Model (TAM) and Theory of Planned Behavior (TPB), which covers variables include Perceived Usefulness, Perceived Ease Of Use, Trust, Subjective Norms, Attitude Toward Use and Behavior Intention. This research examined 100 Millenials in Jakarta, which selected with purposive sampling technique, and tested using PLS SEM statistical analysis method. The results show that Perceived Usefulness has the strongest positive effect on Attitude Toward Use, followed by Trust. While Attitude Toward Use and Subjective Norms have positive effect on Behavior Intention. Whereas, Perceived Ease of Use and Subjective Norms have no significant effect on Attitude Toward Use. It is concluded that Perceived Usefulness and Trust are the two main factors which influenced Millenial's acceptance of e-money applications in Jakarta.
\end{abstract}

Keywords: E-Money Acceptance, Perceived Usefulness, Trust, Millennial Behavior

\section{Introduction}

The volume of e-money transactions in Indonesia have increased every year since 2015, as reported by Bank Indonesia. Whereas significant increase was noted in 2018, where the volume of transactions rise from Rp.12,3 T to Rp. 47 T, and again rise in 2019 to Rp 145 T. Snapcart Indonesia (2019), reported that transactions using emoney applications are significantly higher, where OVO is the most popular (58\%), followed by Gopay (23\%),

Dana (6\%) and LinkAja (1\%), compared to e-money in the form of cards issued by banks (Flazz (BCA), Brizzi (BRI) dan Mandiri e-money) which amount to $11 \%$. Despite this increase, Indonesia's non-cash transactions is still below its region's countries, where Indonesia's non-cash transactions is reported at 4\%, while Vietnam at $11 \%$ and Singapore at $57 \%$ as reported by Grab (2019).

In order to raise awareness and to increase the use of non-cash among the public, business people and government institutions, Bank Indonesia, since 2014, launched the National Non-Cash Program (GNNT). Bank Indonesia is targeting this program to reach at least $25 \%$ of Indonesia's population by 2024 . To regulate the use of e-money in Indonesia, Bank Indonesia released PBI: 11/12 / PBI / 2009 which was later updated in PBI: 18/17 / PBI / 2016), which stated that e-money is issued based on the value of money deposited by the user to the issuer, which is then stored in media in the form of card (chip based) or server (server based). As of April 2020, Bank Indonesia has provided license for 49 companies as e-money issuers for both chip based and server-based emoney.

DailySocial.id (2017) and Ipsos (2020) reported that e-money applications was mainly used by Millenials with the percentage reached $84.81 \%$ and $81 \%$ respectively, compared to the older generations. Millenials is a generation which born in the year of 1980 - 2000 (Ministry of Women's Empowerment and Child Protection of the Republic of Indonesia, 2018). According to Ordun (2015), Millennials is the main market driver in Indonesia, which amount to $33.75 \%$ (88 million people) of the total population of Indonesia (Ministry of Women's Empowerment and Child Protection of the Republic of Indonesia, 2018). This means that increasing usage of emoney applications by Millennials can significantly contribute an increase to Indonesia's non-cash transactions and thus in line with the GNNT program of the government, however, limited studies have been conducted to research this acceptance of e-money applications by Millenials. With this in mind, this research is intended to 
determine factors that have significantly influenced Millenial's acceptance of e-money applications based on the theory of Technology Acceptance Model (TAM) and Theory of Planned Behavior (TPB).

Technology Acceptance Model (TAM) is a theory that is largely used to predict individual acceptance ofinformation technology because of its simplicity. This theory was first introduced by Davis and developed based on Theory of Reasoned Action (TRA) which devoted to user acceptance of information technology (Kim et al, 2009). TAM has two main factors, namely Perceived Usefulness (PU) and Perceived Ease of Use (PEOU) which affect a person's attitude in using technology (Attitude Toward Use (ATU)), which in turn will affect one's intention (Behavior Intention (BI)) to use the technology. One of the shortcomings of TAM is the absence of social factors that are considered to be able to influence a person in using technology (Mathieson, 1991). In addition, existing literatures also suggests that the individual's intention to use a system or technology may result not only from the direct interaction with (and the evaluation of) the system or technology, but can also be influenced by individual psychological attributes, as well as by the social environment in which the individual takes part. (Tian et al , 2020).

Theory of Planned Behavior (TPB) is a theory developed by Icek Ajzen that connects a person's beliefs with behavior (Ajzen, 2005). These beliefs include behavioral beliefs, which is beliefs that form a person's attitudes towards a behavior and normative belief, which is a person's belief to the norms in their environment (subjective norms) that influence their decisions making.

According to Ministry of Women's Empowerment and Child Protection of the Republic of Indonesia (2018), Millennial generation (Millennials) is a generation which born during the year 1980 to 2000. This generation is the first generation which exposed to computer technology and internet since early age. Several characteristics have been noted for Millenials as explained by Gray, et al (2019) and Ministry of Women's Empowerment and Child Protection of the Republic of Indonesia (2018), which includes; technologically savvy, fast learner, wants to do anything fast, having their own strong opinion, and wants to be actively involved. Further, they are also noted as more creative and informative compared to the previous generation, have an open mindset, and also critical thinking. Whereas from marketing point of view,Ordun (2015) stated that Millennials is the main market driver in Indonesia. They are currently within the productive age which make them an important target for every industry in order to maintain its competitive advantage.

As defined in the original TAM theory by Davis (1989), Perceived usefulness is "the degree to which a person believes that using a particular system would enhance his or her performance". Similar to Davis, Kamal (2020) defined perceived usefulness as the extent to which a person feels confident that using the technology will help them in improving their performance. This improvements can be both in the form of physical and non-physical benefits, such as the speed (faster) and better quality of the results compared to the absence of such technology. While Bailey et al. (2017) stated that in term of a mobile payment system, perceived usefulness refers to the extent to which consumers believe that they derive benefits (for example, general convenience, simplification, etc.) by using that payment system, as against other form of payments. Davis (1989) stated that perceived usefulness influenced the users' attitude toward using the technology. The same also reported by Filona \& Misdiyono (2019), which stated that perceived usefulness has significant impact on consumer's attitude toward adoption of e-money. Consumers favorable attitudes on the use of e-money is created when they feel the usefulness of e-money in making a payment process faster and more practical than cash. Chawla \& Joshi (2019), found that perceived usefulness is the main factor that most significantly determines user attitudes towards the use of e-wallets (emoney) in India. Chauhan (2015) pointed out that if people are made aware of the usefulness of m-money (emoney) it will provide a push to use it. Based on the above descriptions, this research hypothesized the following:

Based on the above descriptions, this study hypothesized the following:

\section{H1: Perceived usefulness has positive effect on attitude toward use in using e-money applications}

Davis (1989) explains that perceived ease of use is the extent to which a person believes that it will be easy to use a particular system. According to Mun et al (2017) "perceived ease of use can be interpreted as the extent to which someone believes that they will be free from mental and physical efforts in using a technology" Venkatesh and Davis (2000) stated 4 dimensions in perceived ease of use: (1) interactions with the system are clear and easy to understand, (2) does not require a lot of mental effort to interact with the system, (3) an easy to use system, (4) easy to get system to do what she/he wants to do. Original TAM theory suggests that perceived ease of use is one of the factors that significantly affect consumer's attitude toward using a technology (Davis, 1989). Whereas, in the context of fintech services, Chuang et al. (2016) stated that perceived ease of use of a fintech services will affect consumers' attitude towards using the service, which include indicator such as friendliness of operation processes and ease of downloading the application. This results also supported by Safeena et al. (2011) which stated that, the easier a user perceived to interact with a system, the more likely they will use the system. 
Based on the above descriptions, this study hypothesized the following:

\section{H2: Perceived ease of use has positive effect on attitude toward use in using e-money applications}

Although the original TAM theory does not include trust as one of its factors, however, many studies have included trust in TAM as external variable (Chauhan, 2015). Despite various advantages in the system, lack of trust can act as a potential obstacle to the extensive use of that system. According to Mayer et al. (1995), trust reflects the willingness of a person to be in vulnerability based on positive expectations towards another party's future behavior. While McKnight \& Norman (2001), explained that, when it comes to behavior, trust means that a person voluntarily depends on another person with a feeling of relative security, even though negative consequences are possible. Whereas Robbins (2016) said "trust is conceptualized as a belief about another person's trustworthiness concerning a particular matter at hand that emerges under conditions of unknown outcomes." Relationship between trust and attitude is described by Lin (2011) that, in the context of mobile transactions system (such as e-money applications), users develop trust based on the ability of the stakeholders (the provider of the system) to provide competent service ensuring integrity of user data and transactions, which in turn, influences their attitude. This relationship between trust and attitude is similar to what's stated by Van der Heijden et. al. (2003) "consumer confidence in a new technology will directly affect consumer attitudes towards the technology." Further studies by Chauhan (2015) and Chawla \& Joshi (2019)also noted that trust has significant effect on attitude toward use of a technology.

Based on the above descriptions, this study hypothesized the following:

\section{H3: Trust has positive effect on attitude toward use in using e-money applications.}

Subjective norm, as explained in the theory of planned behaviour (TPB), is a person's perceived social pressure to perform or not to perform a certain behaviour (Ajzen, 1991). In the context of technology, Venkatesh et al. (2003) defined subjective norm as the degree to which an individual perceives that important others believe he/she should use the technology. Yu (2012) identified subjective norm as the most powerful factor in affecting people intention (behavior intention) to use mobile banking. It was found that respondents were significantly influenced by peer groups and interpersonal world-of-mouth. This consistent with Ajzen (1991) which stated that subjective norm is one of the independent determinants of intention (behavior intention).

Further, the significance of subjective norm on users' attitude towards a technological innovation has been established in previous studies (Yu, 2012; Schierz et al., 2010). According to Nguyen et al (2019) the positive results from friends and close relatives regarding the use of technology make consumers more motivated to try the technology themselves.

Based on the above descriptions, this study hypothesized the following:

\section{H4: Subjective norms have positive effect on behavior intention in using e-money applications}

\section{H5: Subjective norms have positive effect on attitude toward use in using e-money application.}

Attitude towards a behavior is defined in TPB, as the degree to which a person has a favorable or unfavorable evaluation or appraisal of the behavior in question (Ajzen, 1991). Where as in the context of technology, TAM defines attitude toward use as the user's evaluation of the desirability of his or her using the system (Mathieson, 1991). Both TAM and TPB have the same definitions for attitude and intentions. Behavior intention is defined by Ajzen (2005), as an individual's perception of whether or not to carry out a behavior in the future as influenced by beliefs and attitudes. Ajzen \& Fishbein (1991) also defines behavior intention as a measure or intensity level of individual's intention to perform a certain behavior. Thus it can be concluded that to know the possibility of an individual's behavior can be seen from the behavior intention of the individual (Go, 2018)

According to Ajzen (1991), attitudes towards a behavior have a significant contributions on the prediction of intentions. Maduku (2014) stated that a person's positive attitude towards a technology will form a strong intention to use that technology. Whereas Nguyen et al. (2019), in the context of Mobile Commerce in Vietnam, stated that the user's attitude toward the use of technology has the strongest effect on their intention to adopt the technology. Previous researches have also found positive effects of attitude toward use on behavior intention (Filona \& Misdiyono, 2019; Chawla \& Joshi, 2019; Chauhan, 2015; Chu \& Chen, 2016).

Based on the above descriptions, this study hypothesized the following:

\section{H6: Attitude toward use has positive effect on behavior intention in using e-money applications}

Based on the above descriptions, the study model for this research is presented as follow: 


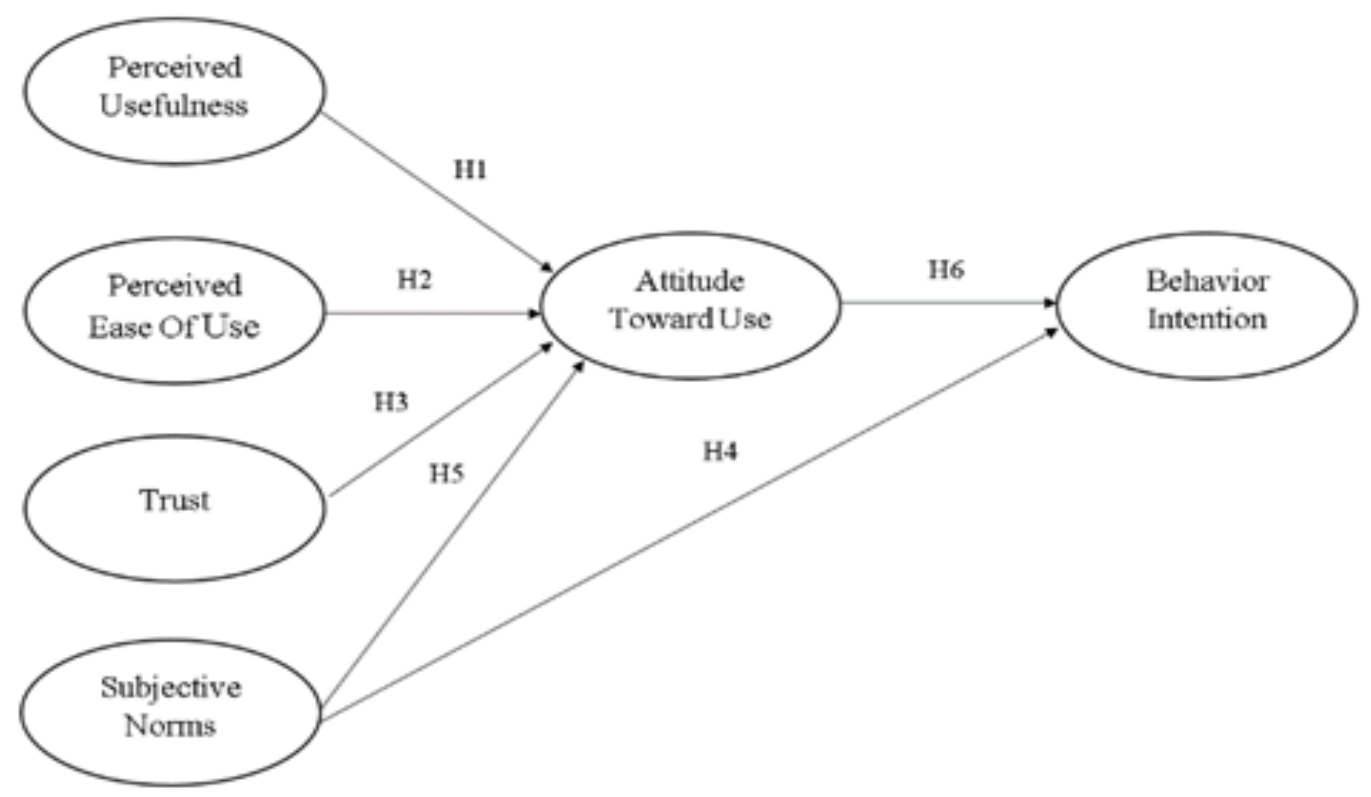

Figure 1. Developing Hypothesis Study Model

\section{Methods}

The population in this research is focused on millennial generation in Jakarta which born in the year 1980 to 2000. Since the population is unknown, the ten time rules is used to measure the minimum sample of this research as stated by hair et al, (2014) "the minimum sample in PLS SEM analysis should be equal 10 times of the largest number of structural paths directed at a particular construct in the structural model." Based on this theory, the minimum sample for this research is 60. According to Hair et al (2014) PLS SEM can achieves high levels of statistical power with small sample sizes but, larger sample sizes increase the precision. In addition, Reinhartz (2009) stated that, in PLS, 100 samples can be sufficient to achieve acceptable levels of statistical power. Thus 100 samples was collected for this research.

The data from respondents is gathered by using questionnaire with 6 points Likert scale which starts from (1) strongly disagree to (6) strongly agree.The 6-point Likert scale is used to avoid neutral answers from respondents. The measurement items are based on literature reviews and previous studies that are used to measure Millenials' acceptance in using e-money applications which presented in table 1.The questionnaire in Indonesian was distributed through online form to Millenials in Jakarta who have regularly used e-money applications for transactions, which selected using purposive sampling technique

Table 1. Study Variable Indicator

\begin{tabular}{|c|c|c|c|}
\hline Construct & Kode & Item & Source \\
\hline \multirow{7}{*}{$\begin{array}{l}\text { Perceived } \\
\text { Usefulness }\end{array}$} & PU1 & $\begin{array}{l}\text { The e-money application makes my transaction } \\
\text { activities easier }\end{array}$ & \multirow{9}{*}{$\begin{array}{l}\text { Ferdyana Lie (2019) } \\
\text { Maduku (2014) }\end{array}$} \\
\hline & PU2 & $\begin{array}{l}\text { By using the e-money application I can complete } \\
\text { more payment transactions in less time. }\end{array}$ & \\
\hline & PU3 & $\begin{array}{l}\text { Using the e-money application allows me to have a } \\
\text { more productive time. }\end{array}$ & \\
\hline & PU4 & $\begin{array}{l}\text { Using e-money applications can help improve my } \\
\text { performance }\end{array}$ & \\
\hline & PU5 & $\begin{array}{l}\text { Using the e-money application makes my } \\
\text { transactions faster and accurate }\end{array}$ & \\
\hline & PU6 & $\begin{array}{l}\text { Using the e-money application increases my } \\
\text { effectiveness in making transactions }\end{array}$ & \\
\hline & PU7 & $\begin{array}{l}\text { By using the e-money application, I can complete } \\
\text { my transactions more effectively. (for example: } \\
\text { payments, transfers, online food, online } \\
\text { motorcycle taxis, etc.) }\end{array}$ & \\
\hline \multirow[t]{2}{*}{$\begin{array}{l}\text { Perceived Ease } \\
\text { of Use }\end{array}$} & PEOU1 & $\begin{array}{l}\text { The way to use the e-money application is clear } \\
\text { and easy to understand }\end{array}$ & \\
\hline & PEOU2 & I don't need to learn much to understand the use of & \\
\hline
\end{tabular}




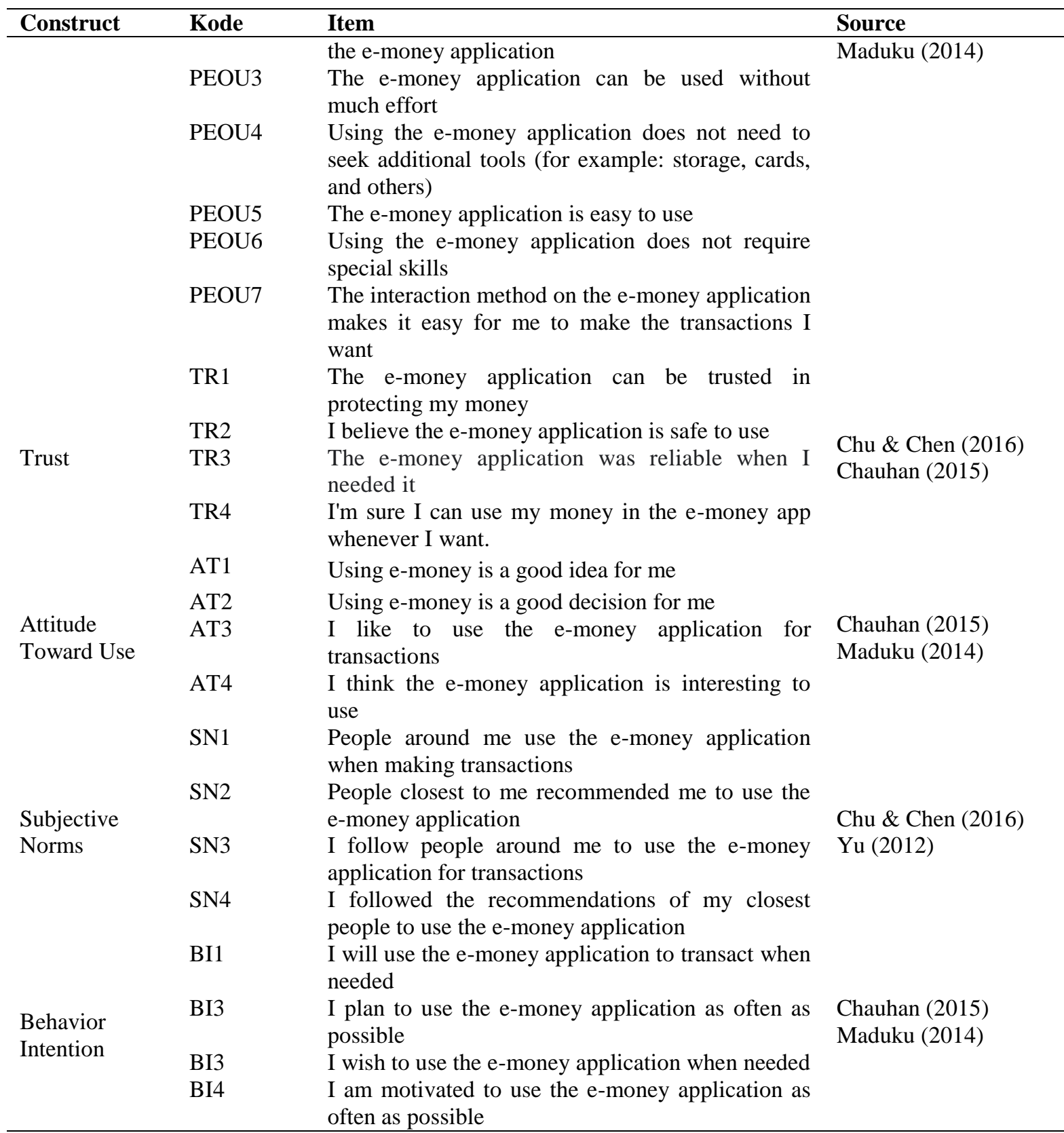

The validity test indicates the extent to which observations are accurately record the behavior that the researcher is intended (Bougie \& Sekaran, 2016). There are two types of validity tests on SmartPLS, namely the convergent validity test and the discriminant validity test. Convergent validity can be assessed by two parameters, namely factor loading and Average variance extracted (AVE). The factor loading value must be a value above 0.6 and ideally 0.7 and the AVE value must be greater than 0.5 to be declared valid (Hair et al, 2014). Meanwhile discriminant validity can be assessed using cross loading. Specifically, the square root of the AVE of each construct should be higher than its highest correlation with any other construct (hair et al, 2014).

Reliability test indicates consistency when repetition of the same event exist (Bougie \& Sekaran, 2016). Reliability test can be determined by Composite Reliability. The value of composite reliability must be greater than 0.7 in order to be declared reliable (Hair et al, 2014). PLS analysis is an analysis that can be used to find a relationship between two or more variables, consisting of exogenous and endogenous variables.

The T-test is carried out to test the coefficients on exogenous variables against endogenous variables directly (Ghozali, 2013). The results of the earlier t-test will be compared with the t table using a significant level of 5\%, in which the hypothesis is accepted if the t-stat $>1,96$ and rejected if the $t$-stat $<1,96$. Beside $t$-value, the hypothesis result can also be reported using $\mathrm{p}$-value in which the hypothesis is accepted if the value of $\mathrm{p}$ value is $<0.05$ and rejected if the $\mathrm{p}$-value $>0.05$. 


\section{Result And Discussion}

Data collection was carried out which focused on the millennial generation who have regularly used e-money applications transactions, which born in the year 1980 - 2000. The results are separated into multiple categories as presented in table 2 .

Table 2. Characteristics of Respondents

\begin{tabular}{llll}
\hline Description & Groups & QTY & \% \\
\hline \multirow{2}{*}{ Gender } & Male & 58 & $58 \%$ \\
& Female & 42 & $42 \%$ \\
Age & $20-25$ & 77 & $77 \%$ \\
& $26-30$ & 9 & $9 \%$ \\
& $31-35$ & 8 & $8 \%$ \\
& $36-40$ & 6 & $6 \%$ \\
Job & Student & 44 & $44 \%$ \\
& Employee & 43 & $43 \%$ \\
& Business & 8 & $8 \%$ \\
E-Money & Other & 5 & $5 \%$ \\
Application & 1 Apps & 23 & $23 \%$ \\
Used & 2 Apps & 41 & $41 \%$ \\
& 4 Apps & 25 & $25 \%$ \\
Frequency & of & 10 & $10 \%$ \\
E-Money Used & 3-2 Times & 19 & $19 \%$ \\
per month & 6-10 Times & 21 & $21 \%$ \\
& $>10$ Times & 32 & $32 \%$ \\
\hline
\end{tabular}

The convergent validity test results can be confirmed by using Factor Loading and average Variance Extracted (AVE). Items and variables will be valid if they have a factor loading value above 0.6 and AVE is greater than 0.5. (Table 3). the discriminant validity test is also confirmed as the square root of the AVE of each construct is higher than its highest correlation with any other construct. (Table 4).

Composite Reliability of all variables is above 0.7 which indicates that all of the above variables are declared reliable. (Table 5).

Testing the direct influence hypothesis is used to test whether there is an effect of exogenous variables directly on endogenous variables. The test criteria state that if the path coefficient is positive and the value of Tstatistics $\geq$ T-table $(1,96)$ then it is stated that there is a positive and significant influence of exogenous variables on endogenous variables. The results of hypothesis testing is provided in Table 6.

Tabel 3. Convergent Validity

\begin{tabular}{llll}
\hline Variabel & Item & F. Loading & AVE \\
\hline \multirow{4}{*}{ PU } & PU1 & 0.852 & \\
& PU2 & 0.828 & \\
& PU3 & 0.790 & \\
& PU4 & 0.637 & 0.624 \\
& PU5 & 0.901 & \\
& PU6 & 0.898 & \\
& PU7 & 0.877 & \\
& PEOU1 & 0.839 & \\
& PEOU2 & 0.789 & \\
PEOU & PEOU3 & 0.810 & \\
& PEOU4 & 0.605 & 0.526 \\
& PEOU5 & 0.905 & \\
& PEOU6 & 0.606 & \\
TR & PEOU7 & 0.809 & \\
& TR1 & 0.889 & \\
AT & TR2 & 0.721 & 0.655 \\
& TR3 & 0.788 & \\
\hline
\end{tabular}




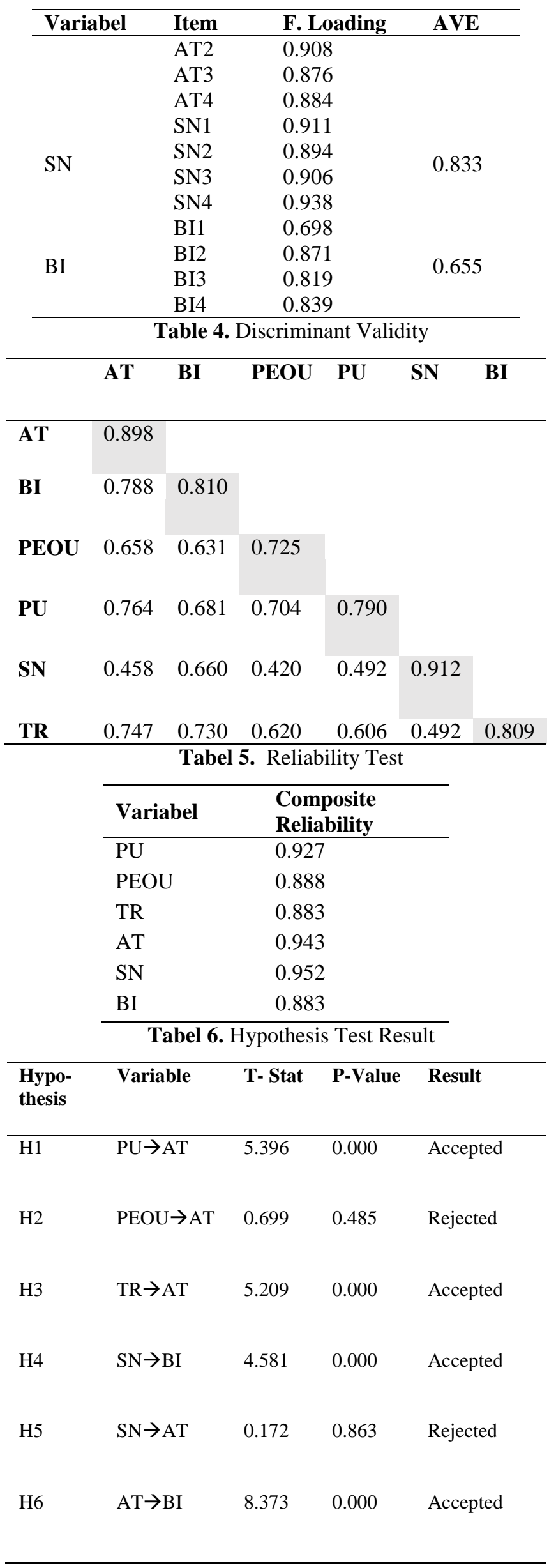


The first hypothesis about the effect of perceived usefulness on attitudes towards use e-money applications is accepted, meaning that the respondents perception about the benefits they got from using e-money applications have positive effects on their acceptance. This results confirmed the original TAM theory and also in line with several previous studies (Filona \& Misdiyono, 2019; Chawla \& Joshi, 2019; Chauhan, 2015). It is stated that "if people are made aware of the benefits of using technology to make transactions quickly and effectively, this will encourage them to use it (Chauhan, 2015). Further, of all the benefits indicators used in this study, transaction speed and effectiveness of e-money applications are factors that most resonate with the characteristics of the Millenials who likes fast and effective technology.

The second hypothesis is rejected, which means that the respondent's perceptions about the ease of using emoney applications have no significant effects on their acceptance. This results is different from the original TAM theory which states that ease of use have positive effects on the user's acceptance of technology. The respondents answer to questionnaire showed that $77 \%$ of them installed two to five e-money applications and use them interchangeably for their transactions, which indicates that the respondents put little importance and have little preference on how (the ease) to use each applications compared to the benefits they got from using these applications. A follow up interview to several respondents confirmed this finding. This results in line with the characteristic of Millennials who's familiar with technology and known as technology savvy. For them, adapting with new technology is not difficult. This also in line with the results of previous studies by Chauhan (2015) and Chawla \& Joshi (2019). It is stated that although intuitively ease of use is important, however only enhancing ease of use would not result into increased acceptance (Chauhan 2015).

The third hypothesis regarding trust is accepted which means that trust has positive effect on attitudes towards using the e-money application. This results in line with the previous study by Chauhan (2015) Chawla \& Joshi (2019) which found that trust is significantly impacting attitude towards using mobile money and mobile wallet in India. Based on questionnaire data, it was found that $81 \%$ of the respondent make at least three transactions per month with the highest make more than 10 transactions per month, these shows that they have trusted the system. The respondents trust the system mostly because they can rely on the ability of system to complete their transactions and in a secured manner.

The forth hypothesis regarding the effect of subjective norms on behavior intention is accepted, which means that social pressure significantly affecting the respondent's behavior intention in using e-money applications. The respondent are most affected by usage of e-money application by other people close to them and their recommendations. This result in line with previous by Nguyen et al. (2019) which stated that positive results from friends and close relatives on the use of technology make consumers more willing to try the technology themselves". Also this results is in line with the original TPB theory.

The fifth hypothesis regarding the effects of subjective norms on attitude toward use is rejected, which means thatalthough subjective norms have positive effects on the respondent's intention to use e-money application, apparently subjective norms do not have significant effects on the respondent's attitude. Based on a follow up interview with several respondents it is noted that the existence of risk involved (losing money) in using e-money applications have created the need on the respondents to experience the system by themselves, before they make decision to use it. Thus in this case, subjective norms have only affects the respondents' intention (the willingness to try) not yet the attitude. This in line with the previous study by Maduku (2014) which stated that the risk of using a technology affects the relationship between subjective norm and attitude. In addition, this results also consistent with the characteristic of Millennials who have critical thinking and wants to have their own opinion (Gray et al, 2019; Ministry of Women's Empowerment and Child Protection of the Republic of Indonesia 2018).

The sixth hypothesis regarding effects of attitude toward use on behaviorintention is accepted, which means that the respondent's intention to use e-money applications is affected by their attitude toward using the system. Thus when users favored the use of the technology, it will affect their intention to use the technology. The respondent data indicated that the respondent's positive attitudes is coming from their interest to take advantage the benefits (fast, effective, easy, reliable, and secure) of using e-money applications for their transactions and thus affect their intentions to use. This result is in line with the original theory of TAM and TPB. Davis (1989) stated that behavior intention is the main dependent variable, where attitude toward use of technology is a key mediator of other variables' influence on behavior intention.

\section{Conclusion}

This study aims to determine factors that influence Millennials' acceptance of e-money application in Jakarta, based on the theory of Technology Acceptance Model (TAM) and Theory of Planned Behavior (TPB) which covers factors include perceived usefulness, perceived ease of use, trust, attitude toward use, subjective norms and behavior intention. It can be concluded that: 1) Perceived usefulness and trust have positive effects on attitude 
toward use, 2) attitude toward use and subjective norm have positive influence on behavior intention, and 3) perceived ease of use and subjective norms do not have significant effect on attitude toward use.

The results of this study suggest that, on top of existing strategy of marketing and operating the system, there are specific characteristics of Millenials that can be targeted by service providers to increase effectiveness of such strategy that, if followed, can increase the acceptance of e-money application by Millenials. Millenials are more interested in the benefits they got from using e-money applications rather than how (the ease) to use the system. Further, Millenials also more interested to be involved (to have experience) when making decision, especially in the existence of risk involved with the behavior (using the system) and thus by only providing them with information about the system would not very much affects their attitude of using the system. Millennials also need the system to be secured and dependable.

With this results, the managerial implications that can be carried out by service providers (e-money application issuer) are include the following: 1) To be more innovative in developing new features (new services) by providing more capability and capacity of transactions within the system, for example by collaborating with various merchants online and offline, etc., 2) providing the users with more benefits such as transactions discounts, bonus balance, special membership, etc., 3) The performance and security of the system and the technology (infrastructure) used also needs to be maintained and increased to ensure good performance and safe use of the system. Monitoring of the security and performance of the system, and also the speed in resolving customer problems (i.e complains) needs to be considered in order to ensure that the best performance is provided to customers, 4) To ensure that more experiential marketing strategy is used to let potential customers (the Millennials) to try and experience themselves the use of e-money applications so they can have their own direct experience which will affects their understanding about the usefulness of using the system (e-money applications) and build trust that will strongly affects their attitude toward using the system.

Considering the limitations of this study, it is suggested that further research can be carried out to include more variables and to cover larger areas with larger sample size to be more comprehensive.

\section{References}

Ajzen, I. (1991). The Theory of Planned Behavior. Organizational Behavior And Human Decision Process, 179121. doi:10.1016/0749-5978(91)90020-T

Ajzen, I. (2005). Attitudes, personality And Behavior 2nd Edition. UK: Open University Press.

Bailey, A. A., Mishra, A., Pentina, I., \& Mimoun, M. S. (2017). Mobile payments adoption by US consumers: an extended TAM. International Journal of Retail \& Distribution Management.

Chauhan, S. (2015). Acceptance of mobile money by poor citizens of India: Integrating trust into the technology acceptance model. Info, 17(3), 58-68. doi:10.1108/info-02-2015-0018

Chawla, D., \& Joshi, H. (2019). Consumer attitude and intention to adopt mobile wallet in India - An empirical study. International Journal of Bank Marketing, 37(7), 1590-1618. doi:https://doi.org/10.1108/IJBM-092018-0256

Chu, T.-H., \& Chen, Y.-Y. (2016). With Good We Become Good: Understanding e-learning adoption by theory of planned behavior and group influences. Computers \& Education, 37-52. doi:10.1016/j.compedu.2015.09.013

Chuang, L.-M., Liu, C.-C., \& Kao, H.-K. (2016). The Adoption of Fintech Service: TAM perspective. International Journal of Management and Administrative Sciences, 1-15.

Dailysocial.id. (2017). Dailysocial.id E-Money Report. Jakarta: Dailysocial. Retrieved from https://dailysocial.id/research/e-money-in-indonesia-survey-2017

Davis, F. (1989). Perceived Usefulness, Perceived Ease of Use, and User Acceptance of Information Technology. MIS Quarterly, 319-339. doi:https://doi.org/10.2307/249008

Filona, \& Misdiyono. (2019). Factors Affecting the Adoption of Electronic Money Using Technology Acceptance Model and Theory of Planned Behavior. Journal of Business Economics, 24(1), 100-113. doi:http://dx.doi.org/10.35760/eb.2019.v24i1.1858

Ghozali, I. (2013). Aplikasi Analisis Multivariate dengan Program IBM SPSS 21 Update PLS Regresi. Badan Penerbit Universitas Diponegoro.

Go, A. M. (2018). Determinants of Mobile Money Adoption:. National Business and Management Conference. Retrieved

from https://www.researchgate.net/publication/338913908_Determinants_of_Mobile_Money_Adoption_Evidence _from_Urban_Philippines

Grab. (2019). Grab For Food: Grab Social Impact Report. Grab. Retrieved from https://assets.grab.com/wpcontent/uploads/media/Grab-Social-Impact-Report-2018-2019.pdf

Gray, S. G., Raimi, K. T., Wilson, R., \& Árvai, J. (2019). Will Millennials save the world? The effect of age and generational differences on environmental concern. Journal of Environmental Management, 394-402. doi:10.1016/j.jenvman.2019.04.071 
Hair, J. F., Hult, T. M., Ringle, C. M., \& Sarstedt , M. (2014). A Primer On Partial Least Squares Structural Equation Modeling (Pls-Sem). United States of America : SAGE Publications.

Heijden, H. v., Verhagen, T., \& Creemers, M. (2003). Understanding online purchase intentions: contributions from technology and trust perspectives. European Journal of Information Systems, 41-48. doi:10.1057/palgrave.ejis.3000445

Indonesia, Ministry of Women's Empowerment and Child Protection of the Republic of Indonesia.. (2019). Profil Generasi Milenial Indonesia.

Ipsos. (2020). The Evolution Of The Digital Wallet: Driving The Next Wave Of Growth. Ipsos. Retrieved from https://www.ipsos.com/sites/default/files/ct/news/documents/2020-02/ipsos_media_conference_-_e-wallet_en_0.pdf

Kamal, S. A., Shafiq, M., \& Kakria, P. (2020). Investigating acceptance of telemedicine services through an extended technology acceptance model (TAM). Technology in Society. doi:10.1016/j.techsoc.2019.101212

Kim, J., Ma, Y. J., \& Park, J. (2009). Are US consumers ready to adopt. Journal of Fashion Marketing and Management: An International Journal, 215-230.

Lie, F. (2019). Factors Contributing To The Adoption Of Fintech In Indonesia: Case Study Of Ovo And Go-Pay. Retrieved from http://library.binus.ac.id/Thesis/RelatedSubject/TS-R-2019-0041

Lin, H.-F. (2011). An empirical investigation of mobile banking adoption: The effect of innovation attributes and knowledge-based trust. International Journal of Information Management, 252-260. doi:https://doi.org/10.1016/j.ijinfomgt.2010.07.006

Maduku, D. K. (2014). Behavioral Intention Towards Mobile Banking Usage By South African Retail Banking Clients . Investment Management and Financial Innovations, , 58-72.

Maduku, D. K. (2014). Comparative analysis of factors influencing customers' attitude towards Internet and cell phone banking services. Journal of Contemporary Management, 120-140.

Mathieson, K. (1991). Predicting User Intentions: Comparing the Technology Acceptance Model with the Theory of Planned Behavior. Information Systems Research, 173-191. doi:10.1287/isre.2.3.173

Mayer, R. C., Davis, J. H., \& Schoorman, D. (1995). An Integrative Model of Organizational Trust. The Academy of Management Review, 709-734. doi:10.2307/258792

Mcknight, D. H., \& Chervany, N. L. (2001). Trust and Distrust Definitions: One Bite at a Time. Trust in Cybersocieties, 27-54. doi:10.1007/3-540-45547-7_3

Mun, Y. P., Khalid, H., \& Nadarajah, D. (2017). Millennials' Perception on Mobile Payment Services in Malaysia. Procedia Computer Science, 397-404.

Nguyen, T. M., Tuan, N. P., \& Hoang, V.-N. (2019). The theory of planned behavior and knowledge sharing: A systematic review and meta-analytic structural equation modelling. VINE Journal of Information and Knowledge Management Systems, 49(1), 76-94. doi:10.1108/VJIKMS-10-2018-0086

Ordun, G. (2015). Millennial (Gen Y) Consumer Behavior, Their Shopping Preferences and Perceptual Maps Associated With Brand Loyalty. Canadian Social Science, 40-55. doi:10.3968/6697

Robbins, B. G. (2016). What is Trust? A Multidisciplinary Review, Critique, and Synthesis. Sociology Compass, 972-986. doi:https://doi.org/10.1111/soc4.12391

Safeena, R., Date, H., \& Kammani, A. (2011). Internet Banking Adoption in an Emerging Economy: Indian Consumer's Perspective. International Arab Journal of e-Technology, 56-64.

Schierz, P. G., Schilkeb, O., \& Wirtz, B. W. (2010). Understanding consumer acceptance of mobile payment services: An empirical analysis. Electronic Commerce Research and Applications, 209-216. doi:10.1016/j.elerap.2009.07.005

Sekaran, U., \& Bougie, R. (2016). Research Methods For Business. Wiley.

Snapchart. (2019). OVO Dominates Digital Payment Market in Indonesia: Study. Retrieved from Snapchart: https://snapcart.global/ovo-dominates-digital-payment-market-in-indonesia-study/

Sumerta, K., \& Wardana, I. m. (2018). Analysis of Intention To Use Electronic Money in Denpasar City: Tam Approach. Archives of Business Research, 6(10), 86-103. doi:10.14738/abr.610.5356.

Tian, X., Prybutok, V., \& Dinulescu, F. M. (2020). Millennials Acceptance of Insurance Telematics: An Integrative. American Business Review, 156-181. doi:https://doi.org/10.37625/abr.23.1.156-181

Venkatesh, V., \& Davis, F. D. (2000). A Theoretical Extension of the Technology Acceptance Model: Four Longitudinal Field Studies. Management Science, 186-204. doi:10.1287/mnsc.46.2.186.11926

Venkatesh, V., Morris, M. G., Davis, G. B., \& Davis, F. D. (2003). User Acceptance of Information Technology: Toward a Unified View. MIS Quarterly, 451.

Wingdes, I. (2020). Ekstensi TAM untuk Memprediksi Niat Menggunakan E-Money di Pontianak. Creative Information Technology Journal, 5(4), 10.24076/citec.2018v5i4.221. doi:10.24076/citec.2018v5i4.221

Yousuf, M. A., \& Wahab, E. B. (2017). The Role of Trust in the Relationship between Quality Factors and Customer Satisfaction in Mobile Banking: A Conceptual Framework. The Social Sciences, 12(4), 712-718. doi:10.36478/sscience.2017.712.718 
Yu, C.-S. (2012). Factors Affecting Individuals to Adopt Mobile Banking. Journal of Electronic Commerce Research, 115. 